\title{
Crystal structure and ion conductivity of a new mixed-anion phosphate
}

\section{$\operatorname{LiMg}_{3}\left(\mathrm{PO}_{4}\right) \mathbf{P}_{2} \mathbf{O}_{7}$}

\author{
Sung-Chul Kim ${ }^{\mathrm{a}}$, Mi-Sun Lee ${ }^{\mathrm{a}}$, Jinyeong Kang ${ }^{\mathrm{a}}$, Young-Il Kim ${ }^{\mathrm{b}}$, Seung-Joo Kim ${ }^{\text {a* }}$ \\ ${ }^{a}$ Department of Chemistry, Division of Energy Systems Research, Ajou University, \\ Suwon 443-749, Republic of Korea \\ ${ }^{b}$ Department of Chemistry, Yeungnam University, Gyeongsan 712-749, Republic of Korea
}

* To whom all correspondences should be addressed

Tel) $+82-31-219-2661$

Fax) +82-31-219-1615

E-mail)sjookim@ajou.ac.kr 


\section{Abstract}

A new lithium-containing phosphate, $\mathrm{LiMg}_{3}\left(\mathrm{PO}_{4}\right) \mathrm{P}_{2} \mathrm{O}_{7}$, was prepared by a solid-state reaction, and it was characterized by an ab initio structure determination method on the basis of synchrotron powder X-ray diffraction data. $\mathrm{LiMg}_{3}\left(\mathrm{PO}_{4}\right) \mathrm{P}_{2} \mathrm{O}_{7}$ was found to be orthorhombic (space group Pnma) with lattice parameters $a=9.0387(1) \AA, b=10.6072(1) \AA, c=8.3065(1)$ $\AA$, and $V=796.39(1) \AA^{3}$. The structure features infinite $\left[\mathrm{Mg}_{3} \mathrm{O}_{10}\right]_{\infty}$ layers that are parallel to the $b c$ plane and that are interconnected along the $a$ axis by $\mathrm{PO}_{4}$ and $\mathrm{P}_{2} \mathrm{O}_{7}$ groups. The $\left[\mathrm{Mg}_{3} \mathrm{O}_{10}\right]_{\infty}$ layer contains $\mathrm{Mg}_{3} \mathrm{O}_{14}$ trimers that are formed by three edge-shared $\mathrm{MgO}_{6}$ octahedra. The $\mathrm{PO}_{4}$ and $\mathrm{P}_{2} \mathrm{O}_{7}$ groups are located alternatingly between $\left[\mathrm{Mg}_{3} \mathrm{O}_{10}\right]_{\infty}$ layers. This gives rise to a three-dimensional framework that contains large tunnels along the directions [100] and [010]; the $\mathrm{Li}^{+}$ions are stabilized in these tunnels. AC impedance spectroscopy shows that $\mathrm{LiMg}_{3}\left(\mathrm{PO}_{4}\right) \mathrm{P}_{2} \mathrm{O}_{7}$ has an ionic conductivity of $3.40 \times 10^{-5} \mathrm{~S} \mathrm{~cm}^{-1}$ at $769 \mathrm{~K}$, with an activation energy of $1.17 \mathrm{eV}$.

Keywords: Mixed-anion phosphate, Crystal structure determination, Synchrotron X-ray diffraction, Lithium ion conductivity. 


\section{Introduction}

Inorganic phosphates have attracted widespread attention in recent years for their potential applications as catalysts [1-3], ion-exchange materials [4-6], optical components $[7,8]$, electrode materials for batteries $[9,10]$, and ionic conductors $[11,12]$. The diverse physicochemical properties of phosphates are attributed to the bonding ability of the tetrahedral $\mathrm{PO}_{4}{ }^{3-}$ group; it can bind to a wide range of structural units. Depending on the number of linked tetrahedra, phosphate anions are classified into orthophosphate, pyrophosphate, and polyphosphate groups. In pyrophosphate $\left(\mathrm{P}_{2} \mathrm{O}_{7}^{4-}\right)$, two $\mathrm{PO}_{4}$ units share one oxygen atom. Polyphosphate contains multiple $\mathrm{PO}_{4}$ units that are connected to each other, resulting in a linear chain $\left(\mathrm{P}_{n} \mathrm{O}_{3 n+1}{ }^{(\mathrm{n}+2)-}\right)$ or in a cyclic framework $\left(\mathrm{P}_{n} \mathrm{O}_{3 n}{ }^{\mathrm{n}-}\right.$ for $\left.\mathrm{n} \geq 3\right)$. In addition, some complex phosphates contain two different types of phosphorus oxyanions [13].

To date, several groups have reported the synthesis of mixed-anion phosphates in which orthophosphate and pyrophosphate anions coexist as independent units in the structure. For instance, single crystals of $\mathrm{Na}_{3} \mathrm{Th}\left(\mathrm{PO}_{4}\right)_{2} \mathrm{P}_{2} \mathrm{O}_{7}$ [14], $\mathrm{KNi}_{3}\left(\mathrm{PO}_{4}\right) \mathrm{P}_{2} \mathrm{O}_{7}$ [15], and $\mathrm{AgM}_{2}\left(\mathrm{PO}_{4}\right) \mathrm{P}_{2} \mathrm{O}_{7}$ $(\mathrm{M}=\mathrm{V}, \mathrm{Cr})[16,17]$ were grown by flux methods, and their structures were determined by $\mathrm{X}$ ray diffraction techniques. $\mathrm{Na}_{4} \mathrm{M}_{3}\left(\mathrm{PO}_{4}\right)_{2}\left(\mathrm{P}_{2} \mathrm{O}_{7}\right)(\mathrm{M}=\mathrm{Mn}, \mathrm{Co}, \mathrm{Ni}, \mathrm{Mg})$ [18,19], $\mathrm{Na}_{4} \mathrm{M}_{5}\left(\mathrm{PO}_{4}\right)_{2}\left(\mathrm{P}_{2} \mathrm{O}_{7}\right)_{2}(\mathrm{M}=\mathrm{Ni})$ [20], and $\mathrm{Na}_{7} \mathrm{M}_{4}\left(\mathrm{PO}_{4}\right)\left(\mathrm{P}_{2} \mathrm{O}_{7}\right)_{4}(\mathrm{M}=\mathrm{Al}, \mathrm{Fe}, \mathrm{Cr})$ [21] were also synthesized and they were found to possess good $\mathrm{Na}^{+}$ion transport properties. The ionic conduction in these compounds is attributed to their three-dimensional framework structures 
that feature corner- and edge-sharing between phosphate anions and $\mathrm{MO}_{6}$ octahedra; the sodium ions are located in the interstitial spaces. Very recently, it was reported that $\mathrm{Na}_{7} \mathrm{~V}_{4}\left(\mathrm{PO}_{4}\right)\left(\mathrm{P}_{2} \mathrm{O}_{7}\right)_{4}$, synthesized by a solid-state reaction, exhibits a high redox voltage and a good cyclability as a cathode material for $\mathrm{Na}^{+}$ion batteries. [22]

While exploring new compounds with mixed-phosphate anions, we successfully synthesized $\mathrm{LiMg}_{3}\left(\mathrm{PO}_{4}\right) \mathrm{P}_{2} \mathrm{O}_{7}$ by a solid-state reaction. This compound belongs to a new structure type that, so far, was unknown. We determined the crystal structure of $\mathrm{LiMg}_{3}\left(\mathrm{PO}_{4}\right) \mathrm{P}_{2} \mathrm{O}_{7}$ by an ab initio method on the basis of synchrotron powder X-ray data. Based on the structural characteristics, the lithium ion conduction was investigated.

\section{Material and methods}

The polycrystalline compound $\mathrm{LiMg}_{3}\left(\mathrm{PO}_{4}\right) \mathrm{P}_{2} \mathrm{O}_{7}$ was prepared by a solid-state reaction, using a mixture of $\mathrm{Li}_{2} \mathrm{CO}_{3}$ (Alfa, 99\%), $\mathrm{MgO}$ (Sigma Aldrich, 99.9\%), and $\left(\mathrm{NH}_{4}\right)_{2} \mathrm{HPO}_{4}$ (Sigma Aldrich, 98+\%), in a 1:3:3 molar ratio. The reagents were mixed well, and they were heated at $773 \mathrm{~K}$ for 8 hours. The resulting amorphous solid was reground and heated to $973 \mathrm{~K}$ for 12 hours under an atmosphere of dry $\mathrm{N}_{2}$. The light gray, polycrystalline product was checked preliminarily by powder X-ray diffractometer (Rigaku DMAX-2200PC, Cu Ka radiation). The composition of the sample was estimated by ICP-OES spectrometer (Varian 720). 
To determine the crystal structure of the compound, the synchrotron X-ray diffraction (sXRD) measurement was performed on beamline 11-BM of the Advanced Photon Source at Argonne National Laboratory. The incident X-rays were vertically collimated by a mirror, and they were monochromated to a wavelength of $0.41308 \AA$ by a double-crystal $\mathrm{Si}(111)$

monochromator. Data were recorded in Debye-Scherer mode using sample loaded in a Kapton capillary with a diameter of $1 \mathrm{~mm}$. Diffraction measurement was carried out in the range $0.5^{\circ} \leq 2 \theta \leq 25.7^{\circ}$, with a step size of $0.002^{\circ}$ and scan speed of $0.01^{\circ} \mathrm{s}^{-1}$.

The lithium ion conductivity of $\mathrm{LiMg}_{3}\left(\mathrm{PO}_{4}\right) \mathrm{P}_{2} \mathrm{O}_{7}$ was measured using AC impedance analyzer between $5 \mathrm{~Hz}$ and $13 \mathrm{MHz}$ (Hewlett Packard Impedance Analyzer 4192A). Sample discs were prepared by uniaxially pressing samples into pellets with a diameter of $10 \mathrm{~mm}$ and a thickness of $2 \mathrm{~mm}$, followed by sintering at $1073 \mathrm{~K}$ for 12 hours under an atmosphere of $\mathrm{N}_{2}$. Silver electrodes were painted onto both faces of the pellet; they were then dried at $723 \mathrm{~K}$ for 2 hours to ensure the formation of good electrical contacts. The samples were equilibrated for 2 hours at each temperature of measurement.

\section{Results and Discussion}

\subsection{Structure determination}

The synchrotron X-ray diffraction data were used for the structural study of $\mathrm{LiMg}_{3}\left(\mathrm{PO}_{4}\right) \mathrm{P}_{2} \mathrm{O}_{7}$. The sample included a small amount ( 4\%) of the impurity $\mathrm{LiMgPO}_{4}$. The 
structure determination was carried out using an ab initio method. The powder pattern was indexed and the unit cell parameters were estimated with the DICVOL program [23]. All of the reflections of the main phase could be indexed with an orthorhombic cell. The figures of merit are $\mathrm{M}(18)=13.0$ and $\mathrm{F}(18)=76.0$. The systematic absences $[(0 k l), k+l=$ odd; $(h k 0)$ and $(h 00), h=$ odd; $(0 k 0), k=$ odd; $(00 l), l=$ odd] suggested that the structure belongs either to the centrosymmetric space group Pnma (No. 62) or to the noncentrosymmetric space group $P n 2_{1} a$ (No. 33). Both space groups turned out to afford practically the same structure solution. Hence, the space group with higher symmetry (Pnma) was chosen. The initial positions of the relatively heavy atoms ( $\mathrm{P}$ and $\mathrm{Mg}$ ) were determined by the direct method using the EXPO2009 program [24]. The positions of the O atoms were determined from the Fourier map using the GFOURIER program [25]. After refinement of the electron densities for the P, $\mathrm{Mg}$, and $\mathrm{O}$ atoms, the residual electron density was calculated. The position of the lithium atom was determined from the resulting difference Fourier map. Refinement of the atomic positions and the isotropic displacement parameters was carried out by the Rietveld method with the FULLPROF program [26], using pseudo-Voigt peak shapes and automatically selected backgrounds.

The final refinement including isotropic thermal parameters led to an acceptable goodness of fit $\left(\chi^{2}=1.69\right)$. The observed, calculated, and difference patterns obtained from the Rietveld refinement against the sXRD data are shown in Fig. 1. The structure parameters 
(lattice parameters, refined atomic positions, and isotropic temperature factors for all of the atoms) and residual indices of $\mathrm{LiMg}_{3}\left(\mathrm{PO}_{4}\right) \mathrm{P}_{2} \mathrm{O}_{7}$ are listed in Table 1. The asymmetric unit contains a total of 12 crystallographically independent atoms in asymmetric unit. $\operatorname{Mg}(2)$ is positioned on an inversion center (Wyckoff site 4a). $\mathrm{P}(2), \mathrm{O}(2), \mathrm{O}(5), \mathrm{O}(7)$, and $\mathrm{Li}(1)$ are located on the mirror plane (Wyckoff site 4c). The remaining atoms $(\mathrm{Mg}(1), \mathrm{P}(1), \mathrm{O}(1), \mathrm{O}(3)$, $\mathrm{O}(4)$ and $\mathrm{O}(6))$ are all located on general positions. Selected bond lengths and bond angles are listed in Table 2.

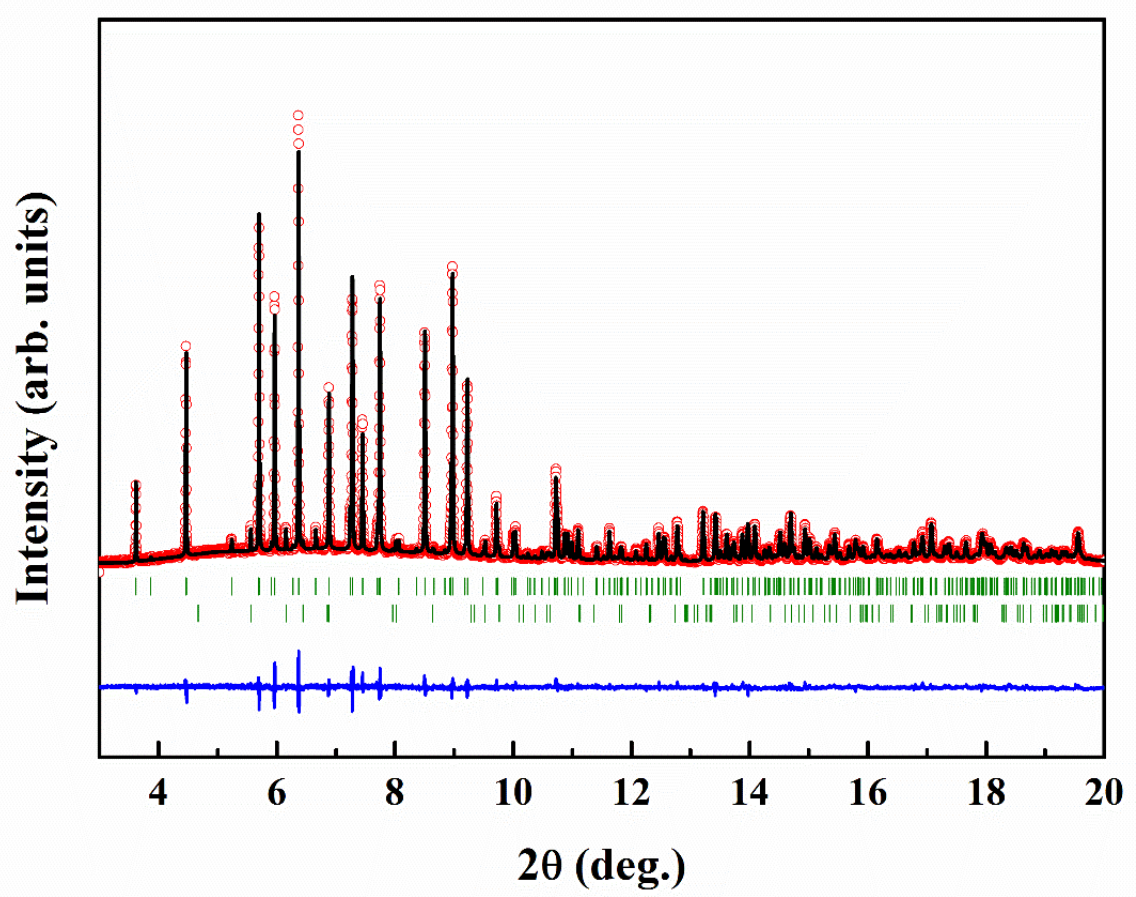

Figure 1. Rietveld refinement of the synchrotron powder XRD profile of $\mathrm{LiMg}_{3}\left(\mathrm{PO}_{4}\right) \mathrm{P}_{2} \mathrm{O}_{7}$. The phase includes a small amount of $\mathrm{LiMgPO}_{4}$ as an impurity. Measured data, fitted results, expected reflection positions, and the difference between measured and fitted results are expressed as red hollow circles, black lines, green vertical lines, and blue solid lines, respectively. 
Table 1. Structural parameters of $\mathrm{LiMg}_{3}\left(\mathrm{PO}_{4}\right) \mathrm{P}_{2} \mathrm{O}_{7}$ refined from synchrotron X-ray diffraction.

\begin{tabular}{|c|c|c|c|c|c|}
\hline \multicolumn{4}{|c|}{ Space group } & \multicolumn{2}{|c|}{ Pnma (No. 62) } \\
\hline \multicolumn{4}{|l|}{$Z$} & \multicolumn{2}{|c|}{4} \\
\hline \multicolumn{4}{|l|}{$a(\AA)$} & \multicolumn{2}{|c|}{$9.0387(1)$} \\
\hline \multicolumn{4}{|l|}{$b(\AA)$} & \multicolumn{2}{|c|}{$10.6072(1)$} \\
\hline \multicolumn{4}{|l|}{$c(\AA)$} & \multicolumn{2}{|c|}{$8.3065(1)$} \\
\hline \multicolumn{4}{|c|}{$V\left(\AA^{3}\right)$} & \multicolumn{2}{|c|}{$796.39(1)$} \\
\hline \multicolumn{4}{|c|}{ Wavelength $(\AA)$} & \multicolumn{2}{|c|}{0.413077} \\
\hline \multicolumn{4}{|c|}{ Step scan increment $\left({ }^{\circ} 2 \theta\right)$} & \multicolumn{2}{|c|}{0.002} \\
\hline \multicolumn{4}{|c|}{$2 \theta$ range $\left(^{\circ}\right)$} & \multicolumn{2}{|c|}{$0.51-25.714$} \\
\hline \multicolumn{4}{|c|}{ No. of observations $(N)$} & \multicolumn{2}{|c|}{12603} \\
\hline \multicolumn{4}{|c|}{ No. of reflections } & \multicolumn{2}{|c|}{566} \\
\hline \multicolumn{4}{|c|}{ No. of structural parameters $(P 1)$} & \multicolumn{2}{|c|}{51} \\
\hline \multicolumn{4}{|c|}{ No. of profile parameters $(P 2)$} & \multicolumn{2}{|c|}{13} \\
\hline \multicolumn{4}{|c|}{$R_{p}=(\Sigma|\mathrm{y}(\mathrm{obs})-\mathrm{y}(\mathrm{calc})|) / \Sigma \mathrm{y}(\mathrm{obs})$} & \multicolumn{2}{|c|}{$4.52 \%$} \\
\hline \multicolumn{4}{|c|}{$R_{w p}=\left[\left(\Sigma \mathrm{w}[\mathrm{y}(\mathrm{obs})-\mathrm{y}(\mathrm{calc})]^{2} / \Sigma \mathrm{wy}^{2}(\mathrm{obs})\right]^{1 / 2}\right.$} & \multicolumn{2}{|c|}{$5.74 \%$} \\
\hline \multicolumn{4}{|c|}{$R_{e x p}=\left[(N-P 1-P 2) / \Sigma \mathrm{wy}^{2}(\mathrm{obs})\right]^{1 / 2}$} & & $2 \%$ \\
\hline$R_{\text {bragg }}=$ & $\Sigma \mid I($ obs $)-I($ calc & l) $/ \Sigma I($ obs $)$ & & & $5 \%$ \\
\hline$\chi^{2}=(R$ & $\left(R_{\mathrm{exp}}\right)^{2}$ & & & & 69 \\
\hline & Wyckoff site & $x$ & $y$ & $z$ & $B\left(\AA^{2} \times 10^{2}\right)$ \\
\hline $\mathrm{P}(1)$ & $8 d$ & $0.2118(2)$ & $0.1093(2)$ & $0.2858(2)$ & $1.22(5)$ \\
\hline $\mathrm{P}(2)$ & $4 c$ & $0.1480(3)$ & 0.75 & $0.2127(4)$ & $1.08(6)$ \\
\hline $\operatorname{Mg}(1)$ & $8 d$ & $0.0463(2)$ & $0.0898(2)$ & $0.6409(2)$ & $0.87(5)$ \\
\hline $\operatorname{Mg}(2)$ & $4 a$ & 0.5 & 0 & 0.5 & $1.47(9)$ \\
\hline $\mathrm{O}(1)$ & $8 d$ & $0.3502(4)$ & $0.0265(3)$ & $0.3006(4)$ & $0.77(10)$ \\
\hline $\mathrm{O}(2)$ & $4 c$ & $0.3914(5)$ & 0.25 & $0.8942(6)$ & $0.67(14)$ \\
\hline $\mathrm{O}(3)$ & $8 d$ & $0.4217(3)$ & $0.1323(3)$ & $0.6399(4)$ & $0.44(10)$ \\
\hline $\mathrm{O}(4)$ & $8 d$ & $0.1490(3)$ & $0.1154(3)$ & $0.1152(4)$ & $0.28(10)$ \\
\hline $\mathrm{O}(5)$ & $4 c$ & $0.3164(5)$ & 0.75 & $0.1890(6)$ & $0.92(14)$ \\
\hline $\mathrm{O}(6)$ & $8 d$ & $0.0989(4)$ & $0.0651(3)$ & $0.4093(4)$ & $0.89(10)$ \\
\hline $\mathrm{O}(7)$ & $4 c$ & $0.2654(6)$ & 0.25 & $0.3352(6)$ & $1.37(15)$ \\
\hline $\operatorname{Li}(1)$ & $4 c$ & $0.3262(18)$ & 0.75 & $0.476(2)$ & $2.6(4)$ \\
\hline
\end{tabular}


Table 2. Selected bond distances $(\AA)$ and angles $\left(^{\circ}\right)$ for $\operatorname{LiMg}_{3}\left(\mathrm{PO}_{4}\right) \mathrm{P}_{2} \mathrm{O}_{7}$.

\begin{tabular}{|c|c|c|c|c|c|c|}
\hline \multirow[t]{5}{*}{$\mathrm{P}(1)-$} & $\mathrm{O}(1)$ & $1.535(4)$ & \multirow[t]{5}{*}{$\operatorname{Mg}(1)-$} & \multicolumn{2}{|l|}{$\mathrm{O}(1)$} & $2.039(4)$ \\
\hline & $\mathrm{O}(4)$ & $1.528(4)$ & & \multicolumn{2}{|l|}{$\mathrm{O}(2)$} & $2.221(4)$ \\
\hline & $\mathrm{O}(6)$ & $1.521(4)$ & & \multicolumn{2}{|l|}{$\mathrm{O}(3)$} & $2.188(4)$ \\
\hline & $\mathrm{O}(7)$ & $1.622(3)$ & & \multicolumn{2}{|l|}{$\mathrm{O}(5)$} & $2.142(3)$ \\
\hline & & & & \multicolumn{2}{|l|}{$\mathrm{O}(6)$} & $1.999(4)$ \\
\hline \multirow[t]{4}{*}{$\mathrm{P}(2)-$} & $\mathrm{O}(2)$ & $1.549(6)$ & & \multicolumn{2}{|l|}{$\mathrm{O}(6)$} & $2.144(4)$ \\
\hline & $\mathrm{O}(3)$ & $1.524(4)$ & & & & \\
\hline & \multirow[t]{2}{*}{$\mathrm{O}(5)$} & $1.535(5)$ & \multirow[t]{4}{*}{$\operatorname{Mg}(2)-$} & \multirow{2}{*}{$\begin{array}{l}\mathrm{O}(1) \\
\mathrm{O}(3)\end{array}$} & $\times 2$ & $2.158(3)$ \\
\hline & & & & & $\times 2$ & $1.955(3)$ \\
\hline \multirow[t]{5}{*}{$\operatorname{Li}(1)-$} & $\mathrm{O}(2)$ & $2.082(17)$ & & \multirow[t]{2}{*}{$\mathrm{O}(4)$} & \multirow[t]{4}{*}{$\times 2$} & $2.057(3)$ \\
\hline & $\mathrm{O}(3)$ & $2.772(15)$ & & & & \\
\hline & $\mathrm{O}(4)$ & $1.848(11)$ & $\mathrm{P}(1)-$ & \multirow[t]{2}{*}{$\mathrm{P}(1)$} & & $2.985(2)$ \\
\hline & \multirow[t]{2}{*}{$\mathrm{O}(5)$} & $2.388(17)$ & & & & \\
\hline & & & $\operatorname{Mg}(1)-$ & \multicolumn{2}{|l|}{$\operatorname{Mg}(2)$} & $3.159(2)$ \\
\hline \multirow{7}{*}{\multicolumn{2}{|c|}{$\begin{array}{l}\mathrm{O}(1)-\mathrm{P}(1)-\mathrm{O}(4) \\
\mathrm{O}(1)-\mathrm{P}(1)-\mathrm{O}(6) \\
\mathrm{O}(1)-\mathrm{P}(1)-\mathrm{O}(7) \\
\mathrm{O}(4)-\mathrm{P}(1)-\mathrm{O}(6) \\
\mathrm{O}(4)-\mathrm{P}(1)-\mathrm{O}(7) \\
\mathrm{O}(6)-\mathrm{P}(1)-\mathrm{O}(7)\end{array}$}} & $113.7(3)$ & \multicolumn{3}{|c|}{$\mathrm{O}(1)-\mathrm{Mg}(1)-\mathrm{O}(3)$} & $79.6(2)$ \\
\hline & & $108.5(4)$ & \multicolumn{3}{|c|}{$\mathrm{O}(1)-\mathrm{Mg}(1)-\mathrm{O}(5)$} & $95.3(2)$ \\
\hline & & $105.2(3)$ & \multicolumn{3}{|c|}{$\mathrm{O}(1)-\mathrm{Mg}(1)-\mathrm{O}(6)$} & $116.0(3)$ \\
\hline & & $113.0(4)$ & \multicolumn{3}{|c|}{$\mathrm{O}(1)-\mathrm{Mg}(1)-\mathrm{O}(6)$} & $86.8(2)$ \\
\hline & & $107.8(4)$ & \multicolumn{3}{|c|}{$\mathrm{O}(2)-\mathrm{Mg}(1)-\mathrm{O}(3)$} & 68.1(2) \\
\hline & & $108.3(3)$ & \multirow{2}{*}{\multicolumn{3}{|c|}{$\begin{array}{l}\mathrm{O}(2)-\mathrm{Mg}(1)-\mathrm{O}(5) \\
\mathrm{O}(2)-\mathrm{Mg}(1)-\mathrm{O}(6)\end{array}$}} & $77.5(2)$ \\
\hline & & & & & & $97.1(2)$ \\
\hline \multirow{2}{*}{\multicolumn{2}{|c|}{$\mathrm{P}(1)-\mathrm{O}(7)-\mathrm{P}(1)$}} & $133.9(2)$ & $\mathrm{O}(2)-$ & $\lg (1)-($ & & $100.1(2)$ \\
\hline & & & $\mathrm{O}(3)-$ & $\lg (1)-($ & & $88.8(2)$ \\
\hline $\mathrm{O}(2)-$ & $(2)-\mathrm{O}(3)$ & $106.9(4)$ & $\mathrm{O}(3)-$ & $\lg (1)-($ & & $90.3(2)$ \\
\hline $\mathrm{O}(2)-$ & $(2)-\mathrm{O}(5)$ & $110.7(5)$ & $\mathrm{O}(5)-$ & $\lg (1)-($ & & $98.4(3)$ \\
\hline $\mathrm{O}(3)-$ & $(2)-\mathrm{O}(3)$ & $110.1(3)$ & $\mathrm{O}(6)-$ & $\lg (1)-($ & & $81.8(2)$ \\
\hline $\mathrm{O}(3)-$ & $(2)-O(5)$ & $111.0(4)$ & & & & \\
\hline & & & $\mathrm{O}(1)-$ & $\operatorname{Ig}(2)-($ & & $180.0(3)$ \\
\hline $\mathrm{O}(2)-$ & $\mathrm{i}(1)-\mathrm{O}(3)$ & $131.5(6)$ & $\mathrm{O}(1)-$ & $\lg (2)-($ & & $97.8(2)$ \\
\hline $\mathrm{O}(2)-$ & $\mathrm{i}(1)-\mathrm{O}(4)$ & $108.6(6)$ & $\mathrm{O}(1)-$ & $\lg (2)-($ & & $82.2(2)$ \\
\hline $\mathrm{O}(2)-$ & $\mathrm{i}(1)-\mathrm{O}(5)$ & $68.8(7)$ & $\mathrm{O}(1)-$ & $\lg (2)-($ & & $91.4(2)$ \\
\hline $\mathrm{O}(3)-$ & $\mathrm{i}(1)-\mathrm{O}(3)$ & $53.5(4)$ & $\mathrm{O}(1)-$ & $\lg (2)-($ & & $88.6(2)$ \\
\hline $\mathrm{O}(3)-$ & $\mathrm{i}(1)-\mathrm{O}(4)$ & $117.7(5)$ & $\mathrm{O}(3)-$ & $\lg (2)-($ & & $180.0(3)$ \\
\hline $\mathrm{O}(3)-$ & $\mathrm{i}(1)-\mathrm{O}(4)$ & $76.7(5)$ & $\mathrm{O}(3)-$ & $\lg (2)-($ & & $85.1(2)$ \\
\hline $\mathrm{O}(3)-$ & $\mathrm{i}(1)-\mathrm{O}(5)$ & $71.5(5)$ & $\mathrm{O}(3)-$ & $\lg (2)-($ & (4) & $94.9(2)$ \\
\hline $\mathrm{O}(3)-$ & $\mathrm{i}(1)-\mathrm{O}(4)$ & $117.7(5)$ & $\mathrm{O}(4)-$ & $\operatorname{Ig}(2)-($ & & $180.0(3)$ \\
\hline $\mathrm{O}(4)-$ & $\mathrm{i}(1)-\mathrm{O}(4)$ & $101.0(5)$ & & & & \\
\hline $\mathrm{O}(4)-$ & $\mathrm{i}(1)-\mathrm{O}(5)$ & $128.9(6)$ & & & & \\
\hline
\end{tabular}

To verify the refined crystal structure model, the bond valence sums (BVSs) were calculated using the BOND_STR program [27]. The calculated BVS for the Li ion is approximately 1.04. The BVSs of the other atoms span the ranges $1.93-2.30(\mathrm{Mg}), 4.81-5.02$ 
$(\mathrm{P})$, and 1.87-2.07 (O); these values are close to the expected valences of 2, 5, and 2 for $\mathrm{Mg}$, $\mathrm{P}$, and $\mathrm{O}$, respectively. The coordination numbers and BVSs for $\mathrm{LiMg}_{3}\left(\mathrm{PO}_{4}\right) \mathrm{P}_{2} \mathrm{O}_{7}$ are listed in Table 3.

Table 3. The coordination number $(\mathrm{CN})$ and bond valences sum (BVS) for $\mathrm{LiMg}_{3}\left(\mathrm{PO}_{4}\right) \mathrm{P}_{2} \mathrm{O}_{7}$.

\begin{tabular}{cccccc}
\hline atom & CN & BVS & atom & CN & BVS \\
\hline $\mathrm{P}(1)$ & 4 & 4.81 & $\mathrm{O}(3)$ & 4 & 2.07 \\
$\mathrm{P}(2)$ & 4 & 5.02 & $\mathrm{O}(4)$ & 3 & 2.00 \\
$\mathrm{Mg}(1)$ & 6 & 1.93 & $\mathrm{O}(5)$ & 4 & 1.93 \\
$\mathrm{Mg}(2)$ & 6 & 2.30 & $\mathrm{O}(6)$ & 3 & 2.03 \\
$\mathrm{O}(1)$ & 3 & 1.93 & $\mathrm{O}(7)$ & 2 & 1.97 \\
$\mathrm{O}(2)$ & 4 & 1.87 & $\mathrm{Li}(1)$ & 6 & 1.04 \\
\hline
\end{tabular}

\subsection{Description of the structure}

The main structural features of $\mathrm{LiMg}_{3}\left(\mathrm{PO}_{4}\right) \mathrm{P}_{2} \mathrm{O}_{7}$ are the infinite $\left[\mathrm{Mg}_{3} \mathrm{O}_{10}\right]_{\infty}$ layers that are parallel to the $b c$ plane. The layers are interconnected along the $a$ axis by alternately ordered $\mathrm{PO}_{4}$ and $\mathrm{P}_{2} \mathrm{O}_{7}$ groups (Fig. 2). This framework forms large tunnels along the two crystallographic directions [100] and [010], in which the $\mathrm{Li}^{+}$ions are located. Each $\mathrm{Mg}(2) \mathrm{O}_{6}$ octahedron shares a pair of trans edges with two $\mathrm{Mg}(1) \mathrm{O}_{6}$ octahedra to form a trimeric unit $\left(\mathrm{Mg}_{3} \mathrm{O}_{14}\right)$. The trimeric $\mathrm{Mg}_{3} \mathrm{O}_{14}$ units are connected to each other through edge-sharing in zigzag directions, which results in an infinite $\left[\mathrm{Mg}_{3} \mathrm{O}_{10}\right]_{\infty}$ layer. 


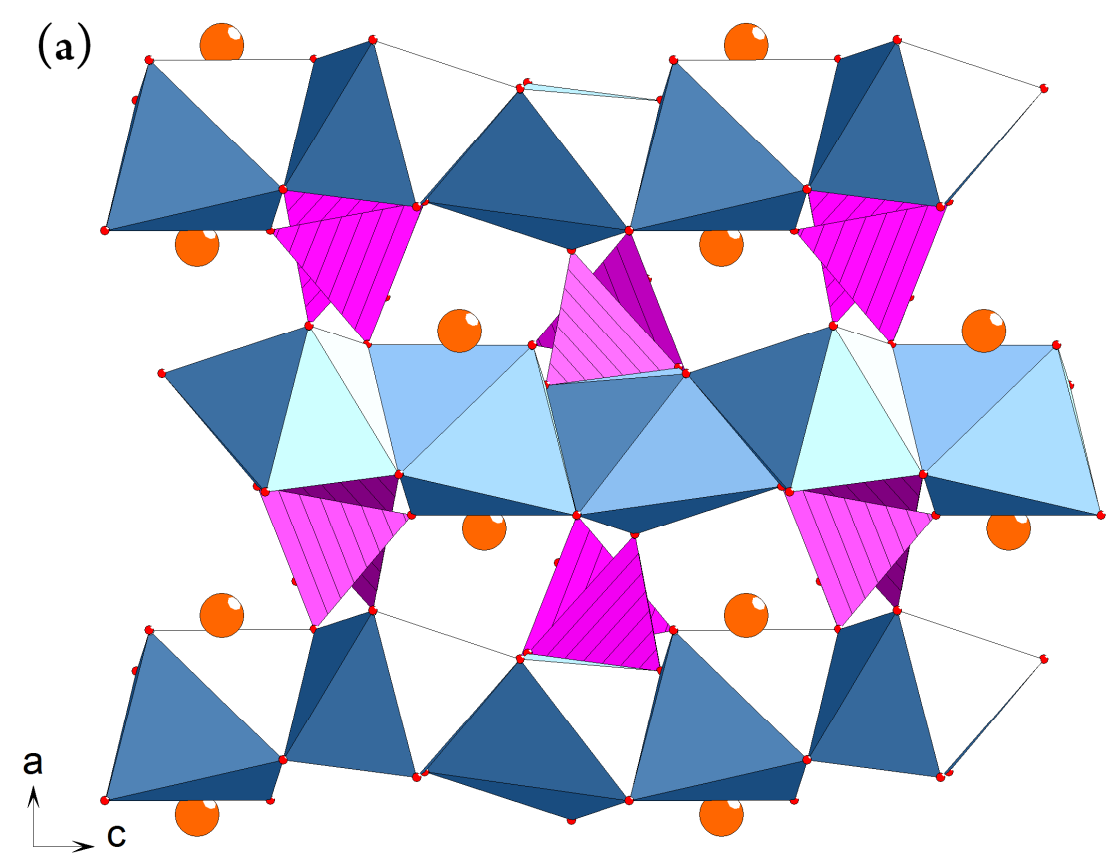

(b)

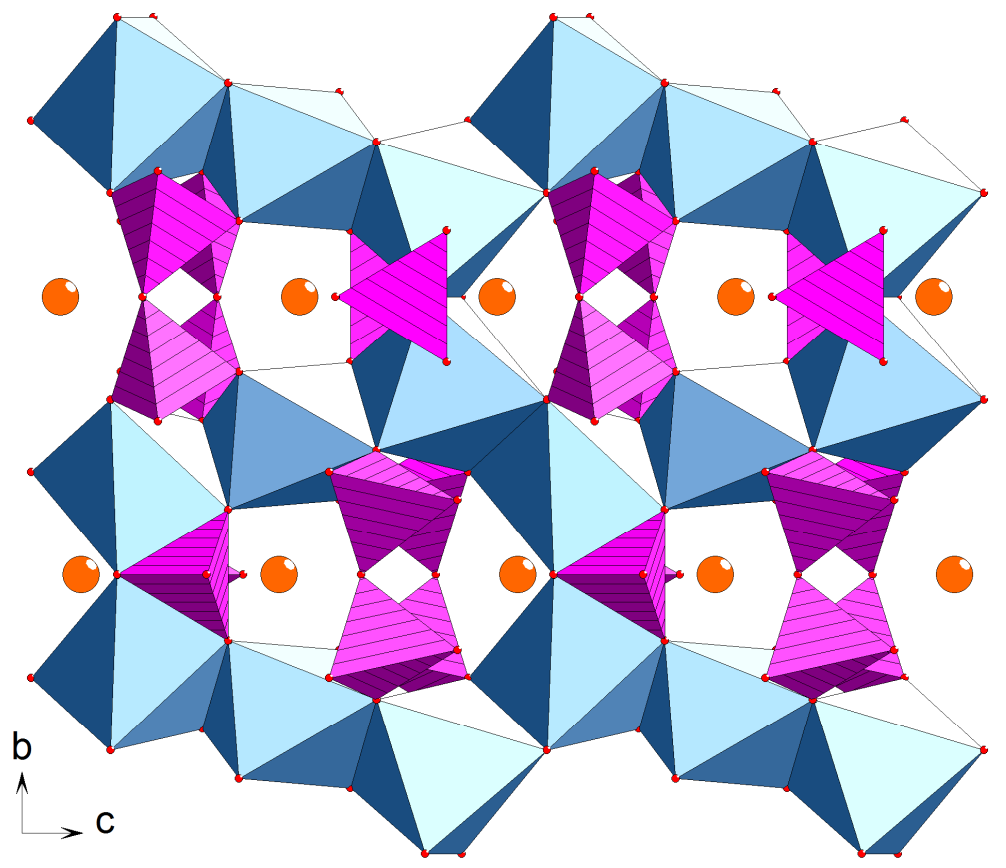

Figure 2. Polyhedral view (a) along the [010] direction, and (b) along the [100] direction of $\mathrm{LiMg}_{3}\left(\mathrm{PO}_{4}\right) \mathrm{P}_{2} \mathrm{O}_{7}$. $\mathrm{Li}^{+}$ions are represented by orange spheres, $\mathrm{MgO}_{6}$ groups by octahedra, and $\mathrm{PO}_{4}$ groups by tetrahedra. 
In the trimeric $\mathrm{Mg}_{3} \mathrm{O}_{14}$ unit, two crystallographically distinct $\mathrm{Mg}$ atoms are each coordinated by six oxygen atoms in a more or less distorted octahedral fashion. Average $\mathrm{Mg}-$ O distances in $\mathrm{Mg}(1) \mathrm{O}_{6}$ and $\mathrm{Mg}(2) \mathrm{O}_{6}$ are 2.122(5) $\AA$ and 2.057(5) $\AA$, respectively. These values are close to the sum of the ionic radii $(2.12 \AA)$ of the ions $\mathrm{Mg}^{2+}$ and $\mathrm{O}^{2-}$ [28]. The centrosymmetric octahedron $\mathrm{Mg}(2) \mathrm{O}_{6}$ is linked to two $\mathrm{Mg}(1) \mathrm{O}_{6}$ octahedra through transedge-sharing, resulting in a $\mathrm{Mg}_{3} \mathrm{O}_{14}$ trimer with a $\mathrm{Mg} \cdot \cdot \mathrm{Mg}$ distance of 3.159(2) $\AA$. The $\mathrm{Mg}(1) \mathrm{O}_{6}$ octahedron also shares a common edge $\mathrm{O}(2)-\mathrm{O}(3)$ with a $\mathrm{P}(2) \mathrm{O}_{4}$ tetrahedron. As a result of these two edge-sharing connections between the $\mathrm{Mg}(1) \mathrm{O}_{6}$ and $\mathrm{PO}_{4}$ groups, the $\mathrm{Mg}(2) \mathrm{O}_{6}$ octahedron is highly distorted: the $\mathrm{O}-\mathrm{Mg}-\mathrm{O}$ bond angles range from $68.1(2)^{\circ}$ to $116.0(3)^{\circ}$ (Fig. 3a). Due to the distortion of the bond angles, the equatorial $\mathrm{MgO}_{4}$ plane of the $\mathrm{Mg}(1) \mathrm{O}_{6}$ octahedron shows a trapezoid-like shape.

There are two crystallographically distinct sites that are occupied by $\mathrm{P}$ atoms, and both types of $\mathrm{P}$ atoms are tetrahedrally coordinated. Two $\mathrm{P}(1) \mathrm{O}_{4}$ tetrahedra share an apical oxygen atom $(\mathrm{O}(7))$ to form a pyrophosphate group $\left(\mathrm{P}_{2} \mathrm{O}_{7}\right)$ with an eclipsed conformation. The $\mathrm{P}_{2} \mathrm{O}_{7}$ unit shares the apical oxygens $\mathrm{O}(1)$ and $\mathrm{O}(6)$ with the $\mathrm{Mg}(1) \mathrm{O}_{6}$ octahedron, and $\mathrm{O}(4)$ with the $\mathrm{Mg}(2) \mathrm{O}_{6}$ octahedron. Two different types of $\mathrm{P}-\mathrm{O}$ distances are observed in the $\mathrm{P}_{2} \mathrm{O}_{7}$ group: the long $\mathrm{P}-\mathrm{O}$ distance $(1.622(3) \AA)$ corresponds to the bridging oxygen atom, and the relatively short distances (between $1.52 \AA$ and $1.54 \AA$ ) correspond to the terminal oxygen atoms. The $\mathrm{P}(1) \cdots \mathrm{P}(1)$ distance is $2.985(2) \AA$ and the $\mathrm{P}(1)-\mathrm{O}(7)-\mathrm{P}(1)$ angle is $133.9(2)^{\circ}$. 
These distances and angles are comparable to those reported for other structures containing $\left[\mathrm{P}_{2} \mathrm{O}_{7}\right]$ pyrophosphates [18-22]. The $\mathrm{P}(2) \mathrm{O}_{4}$ tetrahedron is almost regular, with $\mathrm{P}-\mathrm{O}$ bond lengths that range from 1.524(4) to 1.549(6) $\AA$. All of these distances and angles agree well with those previously observed for $\mathrm{PO}_{4}$ tetrahedra in other phosphate compounds [14-17]. The $\mathrm{P}(2) \mathrm{O}_{4}$ tetrahedron shares common edges $(\mathrm{O}(2)-\mathrm{O}(3))$ shown in Fig. $3 \mathrm{~b}$ with two different $\mathrm{Mg}(1) \mathrm{O}_{6}$ octahedra in a $\mathrm{Mg}_{3} \mathrm{O}_{14}$ trimer. The apical oxygen atom $\mathrm{O}(5)$ of the $\mathrm{P}(2) \mathrm{O}_{4}$ unit is shared with other $\operatorname{Mg}(1) \mathrm{O}_{6}$ octahedron in an adjacent layer.

The lithium ion is surrounded by six oxygen atoms, with $\mathrm{Li}-\mathrm{O}$ distances that range from $1.85(2)$ to $2.77(2) \AA$. The coordination environment consists of four short and two long neighbors and it approximates a strongly distorted trigonal prism (Fig. 3c). The oxygen atoms in the two longer bonds $(\mathrm{Li}-\mathrm{O}(3))$ are connected to two $\mathrm{Mg}(2)$ atoms, while the oxygen atoms in the two shorter bonds $(\operatorname{Li}(1)-\mathrm{O}(4))$ are connected to the phosphorus atom in the $\mathrm{P}_{2} \mathrm{O}_{7}$ group. The remaining oxygens, $\mathrm{O}(2)$ and $\mathrm{O}(5)$ are belong to the vertices of the $\mathrm{PO}_{4}$ tetrahedra. 


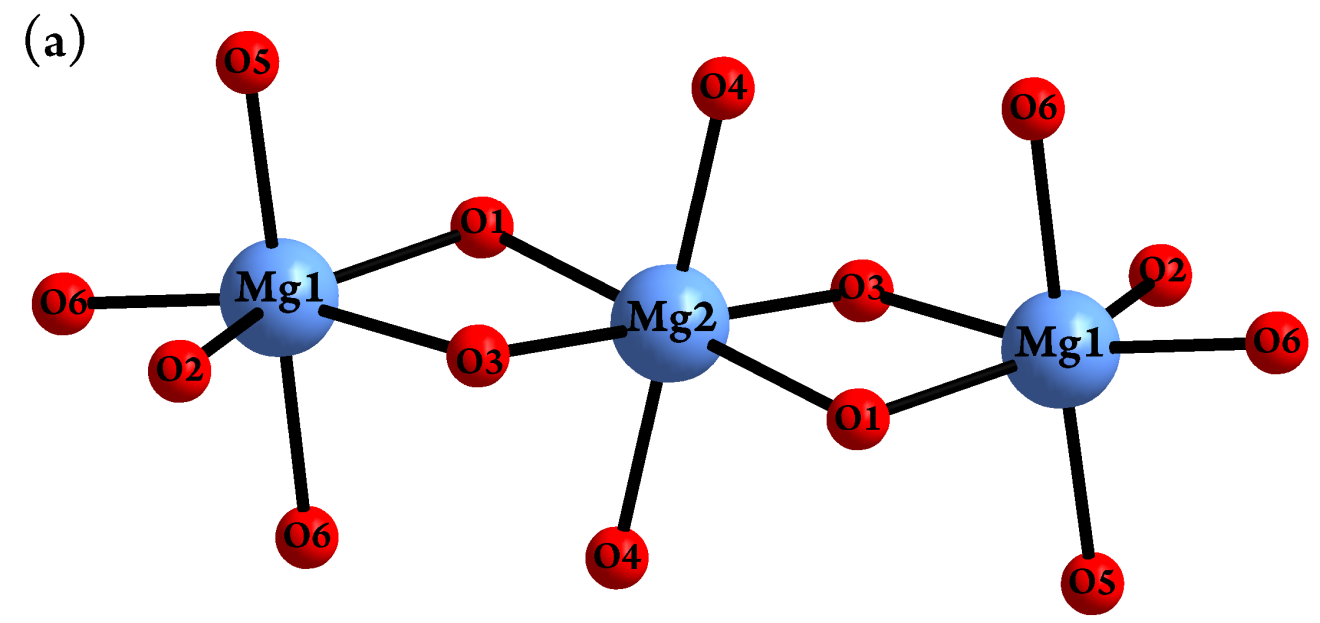

(b)
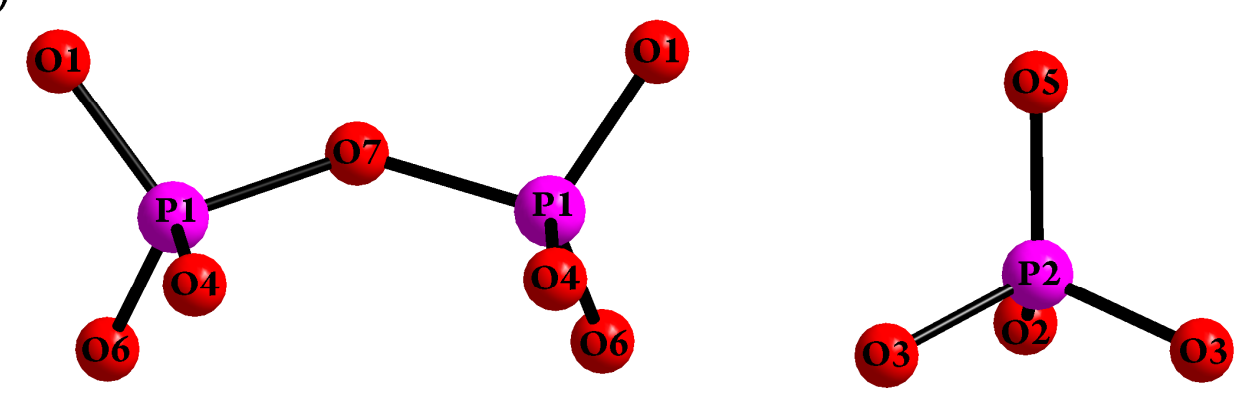

(c)

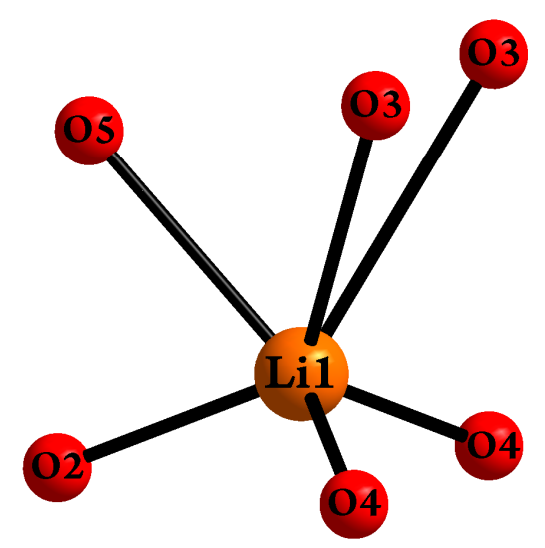

Figure 3. Local structures of (a) the $\mathrm{Mg}_{3} \mathrm{O}_{14}$ group, (b) the $\mathrm{PO}_{4}$ and $\mathrm{P}_{2} \mathrm{O}_{7}$ groups, and (c) the $\mathrm{LiO}_{6}$ group. 


\subsection{Ion conductivity}

Impedance spectra of $\mathrm{LiMg}_{3}\left(\mathrm{PO}_{4}\right) \mathrm{P}_{2} \mathrm{O}_{7}$ pellets, recorded at different temperatures, are shown in Fig. 4a. The resistances were measured from the intercept of the low-frequency end of the semicircle with the real axis of the Nyquist impedance plot. The conductivity $(\sigma)$ was calculated from the resistance $\mathrm{R}$ using the equation $\sigma=l /(\mathrm{R} \cdot S)$, where $l$ and $S$ represent the sample thickness and the electrode surface area, respectively. Fig. $4 \mathrm{~b}$ shows that the conductivity obeys the Arrhenius expression of the form: $\sigma T=A \exp \left(\frac{-E_{a}}{k T}\right)$, where $T$ is the absolute temperature, $A$ is the pre-exponential factor, $k$ is the Boltzmann constant, and $E_{a}$ is the activation energy of the transport process. $\mathrm{LiMg}_{3}\left(\mathrm{PO}_{4}\right) \mathrm{P}_{2} \mathrm{O}_{7}$ shows the highest conductivity $\left(3.4 \times 10^{-5} \mathrm{~S} \mathrm{~cm}^{-1}\right)$ at $769 \mathrm{~K}$, with an activation energy of $1.17 \mathrm{eV}$. Despite the presence of large tunnels that extend along the two directions [100] and [010], where the lithium ions are located, $\mathrm{LiMg}_{3}\left(\mathrm{PO}_{4}\right) \mathrm{P}_{2} \mathrm{O}_{7}$ exhibits a much lower conductivity than those of NASICON-type phosphate and Li-containing garnets:. $2 \times 10^{-3} \mathrm{~S} \mathrm{~cm}^{-1}$ for $\mathrm{LiZr}_{2}\left(\mathrm{PO}_{4}\right)_{3}$ [29], $2.5 \times 10^{-2} \mathrm{~S} \mathrm{~cm}^{-1}$ for $\mathrm{Li}_{5} \mathrm{La}_{3} \mathrm{Ta}_{2} \mathrm{O}_{12}[30]$, and $4.0 \times 10^{-2} \mathrm{~S} \mathrm{~cm}^{-1}$ for $\mathrm{Li}_{7} \mathrm{La}_{3} \mathrm{Zr}_{2} \mathrm{O}_{12}$ [31] at $623 \mathrm{~K}$.

The main reason for the low conductivity observed in $\mathrm{LiMg}_{3}\left(\mathrm{PO}_{4}\right) \mathrm{P}_{2} \mathrm{O}_{7}$ is thought to be the long distance between $\mathrm{Li}$ sites that are available for $\mathrm{Li}$ ion hopping. The $\mathrm{Li} \cdots \mathrm{Li}$ distance $(\sim 6.87 \AA)$ in $\mathrm{LiMg}_{3}\left(\mathrm{PO}_{4}\right) \mathrm{P}_{2} \mathrm{O}_{7}$ is much longer than the distances between $\mathrm{Li}$ sites found in $\mathrm{LiZr}_{2}\left(\mathrm{PO}_{4}\right)_{3}(1.52-3.56 \AA)$ [32], $\mathrm{Li}_{5} \mathrm{La}_{3} \mathrm{Ta}_{2} \mathrm{O}_{12}(1.57-2.96 \AA)$ [33], and $\mathrm{Li}_{7} \mathrm{La}_{3} \mathrm{Zr}_{2} \mathrm{O}_{12}$ (1.70$2.86 \AA$ ) [34]. The conductivity and activation energy of $\mathrm{LiMg}_{3}\left(\mathrm{PO}_{4}\right) \mathrm{P}_{2} \mathrm{O}_{7}$ are comparable to 
those obtained for $\operatorname{LiGd}\left(\mathrm{PO}_{3}\right)_{4}$, a condensed polyphosphate $\left(\sigma=2.5 \times 10^{-5} \mathrm{~S} \mathrm{~cm}^{-1}\right.$ at $771 \mathrm{~K}$, $E_{a}=0.96 \mathrm{eV}$ ) that represents the $\mathrm{Li} \cdots \mathrm{Li}$ distances in the range 5.62-6.65 $\AA$ [35].
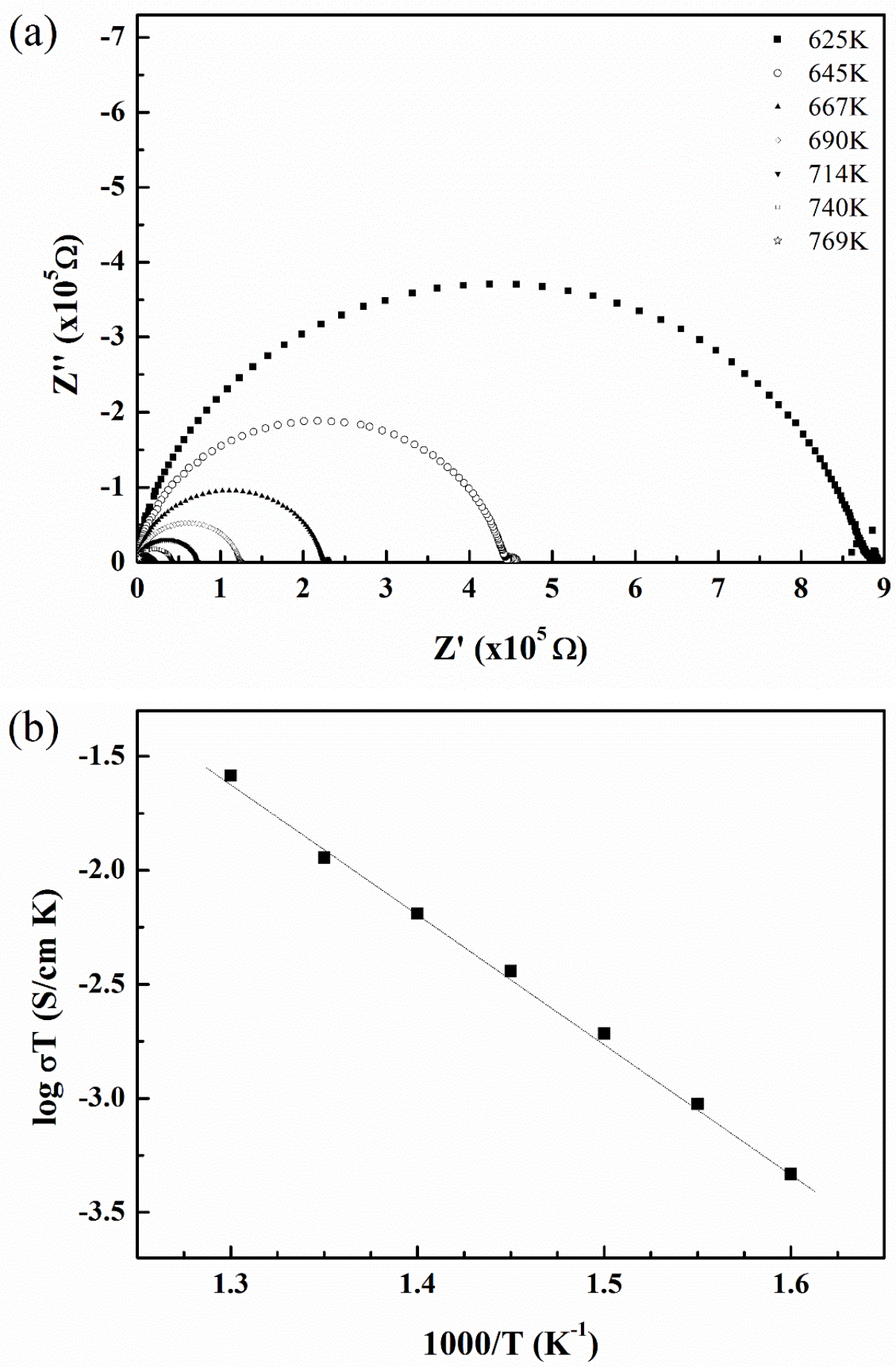

Figure 4. (a) $\mathrm{AC}$ impedance data for $\mathrm{LiMg}_{3}\left(\mathrm{PO}_{4}\right) \mathrm{P}_{2} \mathrm{O}_{7}$ at different temperatures, and (b) Arrhenius plot of the conductivity of $\mathrm{LiMg}_{3}\left(\mathrm{PO}_{4}\right) \mathrm{P}_{2} \mathrm{O}_{7}$. 


\section{Conclusion}

The new mixed-anion phosphate $\mathrm{LiMg}_{3}\left(\mathrm{PO}_{4}\right) \mathrm{P}_{2} \mathrm{O}_{7}$ has been synthesized and its crystal structure and ionic conductivity have been studied. The structure of $\mathrm{LiMg}_{3}\left(\mathrm{PO}_{4}\right) \mathrm{P}_{2} \mathrm{O}_{7}$ consists

of $\left[\mathrm{Mg}_{3} \mathrm{O}_{10}\right]_{\infty}$ layers, with interconnecting $\mathrm{PO}_{4}$ and $\mathrm{P}_{2} \mathrm{O}_{7}$ groups that are located between the layers; this represents a new structure type. $\mathrm{The}^{+} \mathrm{i}^{+}$ions are located in the tunnels that extend along the two directions [100] and [010]. The lithium ionic conductivity of $\mathrm{LiMg}_{3}\left(\mathrm{PO}_{4}\right) \mathrm{P}_{2} \mathrm{O}_{7}$, which is similar to that of $\mathrm{LiGd}\left(\mathrm{PO}_{3}\right)_{4}$, can be understood by the spacing between the Li sites in the structure. This compound may provide a platform for the design of new Li-containing phosphates for applications in the field of solid electrolytes.

\section{Supplementary Material}

Further details of the crystal structure investigations may be obtained from Fachinformationszentrum Karlsruhe, 76344 Eggenstein-Leopoldshafen, Germany (crysdata@fiz-karlsruhe.de) on quoting the deposition number CSD-428811 for $\mathrm{LiMg}_{3}\left(\mathrm{PO}_{4}\right) \mathrm{P}_{2} \mathrm{O}_{7}$

\section{Acknowledgments}

This work was supported by the National Research Foundation (NRF) of Korea (Grant 
Nos. 2010-0013089, 2009-0094046 and 2010-0008039). The authors thank Prof. Daniel P. Shoemaker at the University of Illinois for collecting the sXRD dataset. The use of the Advanced Photon Source at Argonne National Laboratory was supported by the U.S. DOE, Office of Basic Energy Sciences, under Contract No. DE-AC02-06CH11357. 


\section{References}

1. A. Clearfield, D. S. Thakur, "Zirconium and titanium phosphates as catalysts: a review", Applied Catalysis, 26 (1986) 1-26.

2. M. Conte, G. Budroni, J. K. Bartley, S. H. Taylor, A. F. Carley, A. Schmidt, D. M. Murphy, F. Girgsdies, T. Ressler, R. Schlogl, G. J. Hutchings, "Chemically induced fast solid-state transitions of $\omega-\mathrm{VOPO}_{4}$ in vanadium phosphate catalysts”, Science, 313 (2006) 1270-1273.

3. M. W. Kanan, D. G. Nocera, "In situ formation of an oxygen-evolving catalyst in neutral water containing phosphate and $\mathrm{Co}^{2+»,}$ Science, 321 (2008) 1072-1075.

4. A. Clearfield, "Role of ion exchange in solid-state chemistry", Chem. Rev., 88, (1988) 125148.

5. S. T. Wilson, B. M. Lok, C. A. Messina, T. R. Cannan, E. M. Flanigen, “Aluminophosphate molecular sieves: a new class of microporous crystalline inorganic solids", J. Am. Chem. Soc., 104, (1982) 1146-1147.

6. A. Bhaumik S. Inagaki, "Mesoporous titanium phosphate molecular sieves with ionexchange capacity", J. Am. Chem. Soc., 123 (2001) 691-696.

7. M. E. Hagerman, K. R. Poeppelmeier, "Review of the structure and processing-defectproperty relationships of potassium titanyl phosphate: a strategy for novel thin-film photonic devices", Chem. Mater., 7, (1995) 602-621.

8. R. K. Brow, "Review: the structure of simple phosphate glasses", J. Non-Cryst. Solids, 263-264 (2000) 1-28.

9. M. S. Whittingham, "Lithium batteries and cathode materials", Chem. Rev., 104 (2004) 4271-4301.

10. C. Delmas, A. Nadiri, J. L. Soubeyroux, "The nasicon-type titanium phosphates $\mathrm{ATi}_{2}\left(\mathrm{PO}_{4}\right)_{3}(\mathrm{~A}=\mathrm{Li}, \mathrm{Na})$ as electrode materials", Solid State Ionics, 28-30 (1988) 419-423.

11. L. Sebastian, J. Gopalakrishnan, "Lithium ion mobility in metal oxides: a materials chemistry perspective", J. Mater. Chem., 13 (2003) 433-441.

12. N. Anantharamulu, K.K. Rao, M. Vithal, G. Prasad, "Preparation, characterization, impedance and thermal expansion studies of $\mathrm{Mn}_{0.5} \mathrm{MSb}\left(\mathrm{PO}_{4}\right)_{3}(\mathrm{M}=\mathrm{Al}, \mathrm{Fe}$ and $\mathrm{Cr})$ ", $J$. Alloys Compd., 479 (2009) 684-691. 
13. A. Cheetham, G. Ferey, T. Loiseau, "Open-framework inorganic materials", Angew. Chem. Int. Ed., 38 (1999) 3268-3292.

14. B. Kojic-Prodic, M. Sljukic, Z. Ruzic-Toros, "The structure of hexasodium bis[ $\mu-$ (phosphato-O,O')-pyrophosphatothorate(IV)]", Acta Cryst., B38 (1982) 67-71.

15. M. Moutataouia, M. Lamire, M. Saadi, L. E. Ammari, "Potassium trinickel(II) orthophosphate diphosphate, $\mathrm{KNi}_{3}\left(\mathrm{PO}_{4}\right) \mathrm{P}_{2} \mathrm{O}_{7}$ ", Acta Cryst., E70 (2014) i5.

16. A. Grandin, A. Leclaire, M. M. Borel, B. Raveau, "A V(III) phosphate built up from bioctahedral $\mathrm{V}_{2} \mathrm{O}_{10}$ units: $\mathrm{AgV}_{2}\left(\mathrm{PO}_{4}\right) \mathrm{P}_{2} \mathrm{O}_{7} "$, J. Solid State Chem., 115 (1995) 521-524.

17. B. Ayed, "Crystal structure and ionic conductivity of $\mathrm{AgCr}_{2}\left(\mathrm{PO}_{4}\right)\left(\mathrm{P}_{2} \mathrm{O}_{7}\right)$ ", C. R. Chimie, 15 (2012) 603-608.

18. F. Sanz, C. Parada, J. M. Rojo, C. Ruiz-Valero, "Synthesis, structural characterization, magnetic properties, and ionic conductivity of $\mathrm{Na}_{4} \mathrm{MII}_{3}\left(\mathrm{PO}_{4}\right)_{2}\left(\mathrm{P}_{2} \mathrm{O}_{7}\right)(\mathrm{MII}=\mathrm{Mn}, \mathrm{Co}, \mathrm{Ni})$ ", Chem. Mater., 13 (2001) 1334-1340.

19. R. Essehli, B. E. Bali, S. Benmokhtar, H. Fuess, I. Svoboda, S. Obbade, "Synthesis, crystal structure and infrared spectroscopy of a new non-centrosymmetric mixed-anion phosphate $\mathrm{Na}_{4} \mathrm{Mg}_{3}\left(\mathrm{PO}_{4}\right)_{2}\left(\mathrm{P}_{2} \mathrm{O}_{7}\right)$ ", J. Alloy. Compd., 493 (2010) 654-660.

20. F. Sanz, C. Parada, J. M. Rojo, C. Ruiz-Valero, "Crystal structure, magnetic properties, and ionic conductivity of a new mixed-anion phosphate $\mathrm{Na}_{4} \mathrm{Ni}_{5}\left(\mathrm{PO}_{4}\right)_{2}\left(\mathrm{P}_{2} \mathrm{O}_{7}\right)_{2}$ ", Chem. Mater., 11, (1999) 2673-2679.

21. M. de la Rochère, A. Kahn, F. d'Yvoire, E. Bretey, "Crystal structure and cation transport properties of the ortho-diphosphates $\mathrm{Na}_{7}\left(\mathrm{MP}_{2} \mathrm{O}_{7}\right)_{4} \mathrm{PO}_{4}(\mathrm{M}=\mathrm{Al}, \mathrm{Cr}, \mathrm{Fe})$ ", Mat. Res. Bull., 20 (1985) 27-34.

22. S. Y. Lim, H. Kim, J. Chung, J. H. Lee, B. G. Kim, J. J. Choi, K. Y. Chung, W. Cho, S. J. Kim, W. A. Goddard III, Y. Jung, J. W. Choi, "Role of intermediate phase for stable cycling of $\mathrm{Na}_{7} \mathrm{~V}_{4}\left(\mathrm{P}_{2} \mathrm{O}_{7}\right)_{4} \mathrm{PO}_{4}$ in sodium ion battery", Proc. Natl. Acad. Science, 111 (2014) 599-604.

23. A. Boultif, D. Louër, "Powder pattern indexing with the dichotomy method", J. Appl. Cryst., 37 (2004) 724-731.

24. A. Altomare, M. Camalli, C. Cuocci, C. Giacovazzo, A. Moliterni, R. Rizzi, "EXPO2009: structure solution by powder data in direct and reciprocal space" J. Appl. Cryst., 42 (2009) 1197-1202. 
25. J. Gonzales-Platas and J. Rodriguez-Carvajal, Graphic Fourier Program GFOURIER Version 3.200, Laboratoire Leon Brillouin, Saclay, France, 2003.

26. J. Rodriguez-Carvajal, "Recent developments of the program FULLPROF", Commission on Powder Diffraction (IUCr) Newsletter, 26, (2001) 12-19.

27. D. Altermatt, I. D. Brown, "Bond-valence parameters obtained from a systematic analysis of the Inorganic Crystal Structure Database”, Acta Cryst., B41 (1985) 244-247.

28. R. D. Shannon, "Revised effective ionic radii and systematic studies of interatomic distances in halides and chalcogenides", Acta Cryst., A32 (1976) 751-767.

29. M. Casciola, U. Costantino, L. Merlini, I. G. Krogh Andersen, E. Krogh Andersen, "Preparation, structural characterization and conductivity of $\operatorname{LiZr}_{2}\left(\mathrm{PO}_{4}\right)_{3}$ ", Solid State Ionics, 26 (1988) 229-235.

30. V. Thangadurai, H. Kaack, W. Weppner, "Novel Fast Lithium Ion Conduction in GarnetType $\mathrm{Li}_{5} \mathrm{La}_{3} \mathrm{M}_{2} \mathrm{O}_{12}(\mathrm{M}=\mathrm{Nb}, \mathrm{Ta}) "$, J. Am. Ceram. Soc., 86 (2003) 437-440.

31. R. Murugan, V. Thangadurai, W. Weppner, "Fast Lithium Ion Conduction in GarnetType $\mathrm{Li}_{7} \mathrm{La}_{3} \mathrm{Zr}_{2} \mathrm{O}_{12}$, Angew. Chem. Int. Ed., 46 (2007) 7778-7781.

32. M. Catti, A. Comotti, S. Di Blas, "High-Temperature Lithium Mobility in $\alpha-\mathrm{LiZr}_{2}\left(\mathrm{PO}_{4}\right)_{3}$ NASICON by Neutron Diffraction”, Chem. Mater., 15 (2003) 1628-1632.

33. E. J. Cussen, "The structure of lithium garnets: cation disorder and clustering in a new family of fast $\mathrm{Li}^{+}$conductors", Chem. Commun., (2006) 412-413.

34. H. Xie, J. A. Alonso, Y. Li, M. T. Fernandez-Díaz, J. B. Goodenough, "Lithium Distribution in Aluminum-Free Cubic $\mathrm{Li}_{7} \mathrm{La}_{3} \mathrm{Zr}_{2} \mathrm{O}_{12}$ ", Chem. Mater., 23 (2011) 3587-3589.

35. H. Ettis, H. Naili, T. Mhiri, "The crystal structure, thermal behaviour and ionic conductivity of a novel lithium gadolinium polyphosphate $\mathrm{LiGd}\left(\mathrm{PO}_{3}\right)_{4}$ ", J. Solid State Chem., 179 (2006) 3107-3113. 
Polyhedral view of $\mathrm{LiMg}_{3}\left(\mathrm{PO}_{4}\right) \mathrm{P}_{2} \mathrm{O}_{7} . \mathrm{Li}^{+}$ions are represented by orange spheres, $\mathrm{MgO}_{6}$ groups by octahedra, and $\mathrm{PO}_{4}$ groups by tetrahedra.

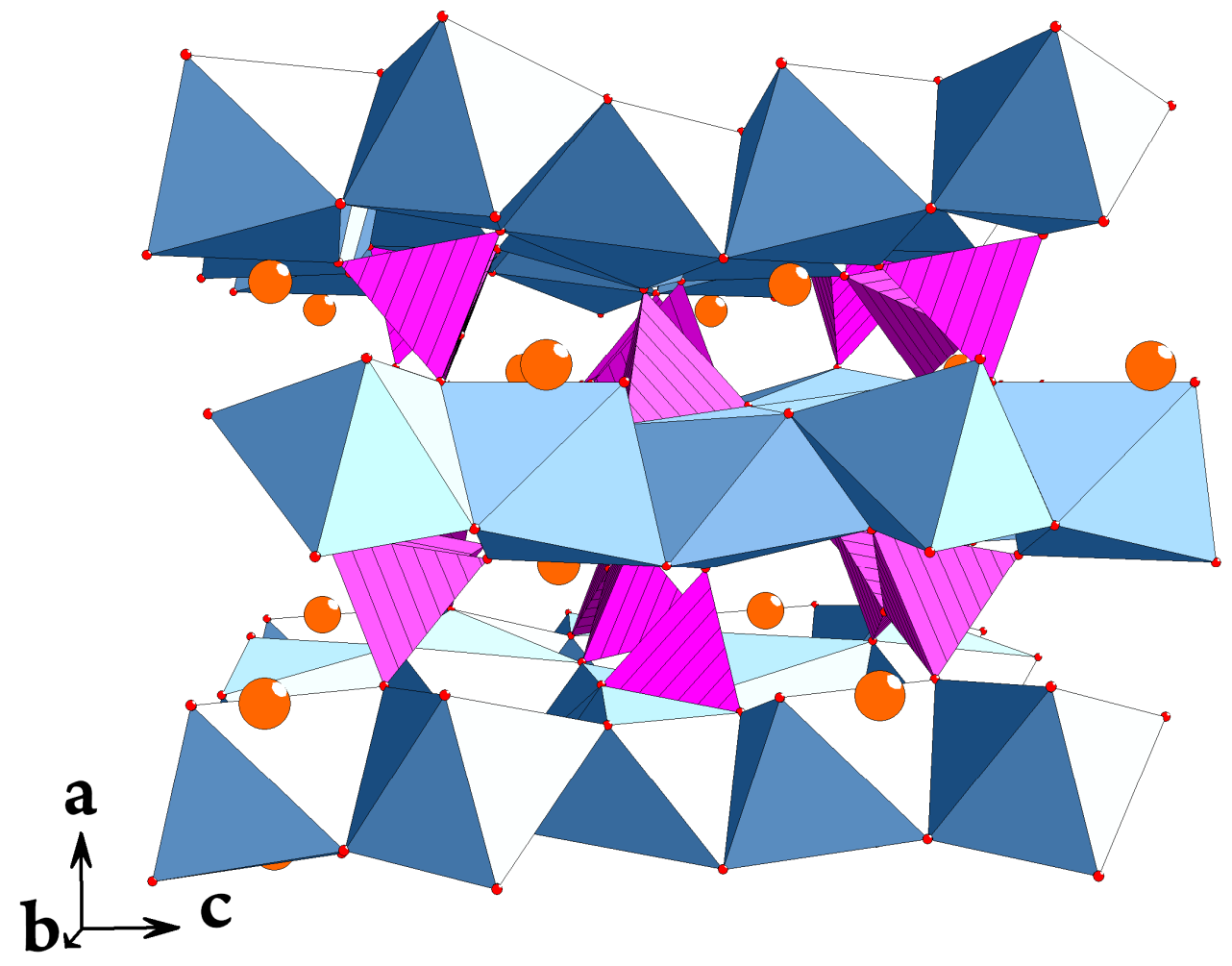

